\title{
Reflexive-with-Dative Construction in Russian and Bulgarian
}

\author{
Elena Ivanova \\ Faculty of Philology \\ St. Petersburg State University \\ St. Petersburg, Russian Federation \\ e-mail: eli2403@yandex.com
}

\begin{abstract}
Russian and Bulgarian possess formally similar reflexive constructions with the dative of experiencer, which have the common meaning of an uncontrolled/involuntary action. The paper brings forward the points of similarity and difference in semantics, co-occurrence patterns, stylistic behavior of these constructions in the two languages.
\end{abstract}

Keywords-Reflexive-with-Dative Construction; reflexivization; syntax; Russian; Bulgarian; Slavic languages

\section{INTRODUCTION}

In Russian, the Reflexive-with-Dative Construction is a product of the reflexivization that demotes the agentive from the subject position to the indirect object position attributing to it the semantic role of the experiencer. The resulting construction acquires the meaning of an "inexplicable ability to do something well" or of inability for "maintaining oneself in a certain state" $[1]$ :

Lučše vsego ja rabotaju na dače. $\rightarrow$ Lučše vsego mne rabotaetsja na dače.

'My working goes best at the country cottage.'

(the second sentence means literally 'Best of all it works itself to me at the country cottage')

Ja ne spal vsju noč. $\rightarrow$ Mne ne spalos' vsju noč.

'I could not sleep all the night.'

(the second sentence means literally 'It did not sleep itself to me all the night')

There is a formally similar model in the South Slavic languages, cf. Bulgarian:

Ne mi se eksperimentira.

'I do not feel like experimenting.'

(literally, 'It does not experiment itself to me') and

Xodi mi se na kino.

'I feel like going to the movies.'

(literally, 'It goes itself to me to the movies'), and Serbian:

Ne spava mi se. Ne čita mi se.

'I do not feel like sleeping. I do not feel like reading.'
At the same time, the presence of this model in West Slavic is somewhat limited, cf. Polish:

Dobrze mi się pracuje.

'My working goes well.'

The equivalence of all these structures and the conditions licensing their derivation in all those languages should not be taken for granted. In what follows the focus will be made on the two languages where these constructions are common, Russian and Bulgarian, and then other Slavic languages will be touched upon briefly.

\section{STRUCTURAL AND DERIVATIONAL PECULIARITIES}

The rules of derivation of this construction in Russian have been described with precision [2]. For the similar Bulgarian form, available studies $[3 ; 4]$ reveal the minimum of grammatical constraints on its derivation. In particular, this construction, unlike its Russian counterpart:

a) may be freely formed from reflexive verbs:

Ne mi se smee. Ne mi se šeguva.

'I do not feel like laughing. I do not feel like joking.'

and intransitive verbs:

Ne mi se vrăšta. Ne mi se razgovarja.

'I do not feel like coming back. I do not feel like talking.'

cf. Russian:

*Mne ne smeeetsja. *Mne ne vozvraščaetsja.

b) produces affirmative and negative forms regularly:

Pătuva mi se. - Ne mi se pătuva.

'I feel like traveling. - I do not feel like traveling.'

Puši mi se. - Ne mi se puši.

'I feel like smoking. - I do not feel like smoking.'

c) permits the formation of inchoative derivatives:

spi mi se $\rightarrow$ dospa mi se $\rightarrow$ dospiva mi se; 
'I feel like sleeping $\rightarrow$ I felt like sleeping $\rightarrow$ I start to feel like sleeping';

jade mi se $\rightarrow$ prijade mi se $\rightarrow$ prijažda mi se;

'I feel like eating $\rightarrow$ I felt like eating $\rightarrow$ I start to feel like eating.'

d) may include the specified object of the desired action (cf. discussion in [5]);

Pătuva mi se, nosjat mi se krasivi drexi, xodi mi se na teatăr i v restorant. (D. Petrunova)

'I feel like traveling, I am inclined to wear beautiful clothes, to go to the theater and to the restaurant.';

$\mathrm{V}$ edin moment useštaš kak ti se vdiga skandal.

'At one point you sense that you feel like creating a scandal.'

Ne znam kakvo mi se raboti.

'I do not know what is that I feel like doing.'

\section{DIFFERENCES IN INTERPRETATIONAL COMPONENTS}

However, a straightforward collation of the derivative mechanisms of this model in Russian and Bulgarian would be misleading, as these constructions differ in their interpretational components. The principal difference in the meaning between the Russian and Bulgarian constructions has to do with the fact that the interpretation of the Russian model includes the presupposed component $\mathrm{X}$ is (currently) doing $\mathrm{P}$ [2], while such presupposition is absent from the meaning of the Bulgarian construction. This determines a different temporal reference for the state of the subject and the action induced by this state: in Russian the state of the speaker is associated with the success/failure of the process currently underway, while the Bulgarian construction is related to the forthcoming action (this is why it is called in Bulgarian linguistics želatelna konstrukcija [4]).

Thus, the Russian:

Segodnja mne otlično rabotaetsja.

'Today my working goes splendidly.'

marks the success of a (creative) process, while the Bulgarian

Raboti mi se.

'I feel like working.'

purports a wish to work, however surprising it might be to the speaker him-/herself. Cf. the following examples in Russian:

Rabotalos $\square$ xorošo, žal $\square$ bylo otryvat $\square$ sja. (V. Rybakov)

'My working went well, I hated to interrupt it.'

and Bulgarian

Raboti mi se, a păk rabota njama.

'I feel like working, though there is no work.'
Consequently, the translation of the Bulgarian structures with the desiderative meaning into Russian requires the inclusion of a predicate of volition (similar to the English feel like):

Ne mi se razxožda. - Mne ne xočetsja guljat $\square /$ Menja ne tjanet na ulicu.

'I do not feel like taking a walk/I have no inclination to go out.'

Spi mi se. - Spat $\square$ oxota.

'I feel like sleeping.'

Ne mi se razkazva sega. - Mne sejčas neoxota rasskazyvat $\square$.

'I do not feel like telling stories now.'

Common to the meaning of the constructions in question in the two languages is semantic component relating to the involuntary and inexplicable nature of the inclination towards the action, whether contemporaneous (in Russian) or forthcoming (in Bulgarian).

The semantic difference in the presupposed component in the two languages influences the selection of predicates in the generation of the construction and the co-occurrence behavior of these predicates.

\section{Semantic Types of the InVolved Predicates}

The examined construction in Russian requires predicates having the semantic features "dynamic", "durative", "human subject" [2]. A predominant, but not obligatory condition for a verb to be included in this structure is, indisputably, the presence of the feature "controllable". The eligibility of a predicate is largely conditioned by its aptness to be reinterpreted as an actual "pastime", as an activity which involves and absorbs a person in a given time interval:

Ja sprosila: kak tam ležitsja, $\mathrm{v}$ ètoj barokamere? (M. Palej)

'I asked how (he) felt when lying in that altitude chamber.'

Kak-to vse grustilos $\square$, kak-to ne pisalos $\square$. (G. Alekseev)

'There was a kind of pining, a kind of no momentum to write.'

Emu kazalos $\square$, čto togda osobenno sladko elos $\square$ i pilos $\square$, krepko spalos $\square$ i legko dyšalos $\square$.

'It seemed to him that at that time eating and drinking was especially sweet, sleeping was especially sound, breathing was especially deep.'

For the Bulgarian construction, contrary to Russian, the feature "durative" appears to be irrelevant, as the whole structure refers to a future and not contemporaneous action. Consequently, predicates of momentary actions in imperfective are allowed:

Pribira mi se veče vkăšti . 
'I feel like going home now.'

Ne mu se vlizaše vătre.

'He did not feel like going inside.'

Ne mi se stave.

'I do not feel like getting up (from bed).'

Ne mi se skačaše dolu, straxuvax se.

'I did not feel like jumping down, I was scared.'

Neither relevant for the Bulgarian construction is the feature "controllability", cf. predicates of uncontrolled actions in:

Plače mi se.

'I feel like crying.'

Ne mi se spi.

'I do not feel like sleeping.'

Kato na lǎv mi se reveše, kato na div zvjar. (an example from [6])

'I felt like howling like a lion, like a wild animal.'

\section{Co-OCCurRence Potential of THE RUSSIAN AND BULGARIAN CONSTRUCTIONS}

The semantic difference between the Russian and Bulgarian constructions also influences the co-occurrence potential. The Russian structure implies the acknowledgment of the successful and "smooth" flow of the process [1], therefore the vast majority of such occurrences (in the affirmative form) is accompanied by an adverbial modifier of evaluation:

V takuju pogodu vsegda xorošo mečtaetsja

'In such a weather dreaming goes well.'

Zdes $\square \quad$ emu i dyšalos $\square \quad$ i dumalos $\square \quad$ vol $\square$ gotno (Ch. Ajtmatov)

'Here his breathing and thinking went freely.'

The position of these modifiers may be filled by the intensifiers kak, tak:

Ax, ja našel v Pribaltike takoe mestečko, tam tak pišetsja, tak rabotaetsja! (V. Rozov)

'I found such a place in the Baltics, writing goes so (well) there, working goes so (well) there!'

Kak spalos $\square$ ?

'How was (your) sleeping going?'

$\mathrm{Nu}$, kak tebe zaveduetsja?

'Well, how is your managering going?'

The absence of evaluation modifiers in Russian is possible only with the verbs of creative activities:
Mne ves $\square$ den $\square$ segodnja rabotalos $\square$ / pisalos $\square$ / sočinjalos $\square$. day.'

'My working/writing/composing went (so well) all the

The negative meaning (i. e. "a process going on with difficulties, to no success") is set up either by appropriate adverbs or by a negative particle:

Mne pri zakrytoj fortočke ploxo spitsja.

'My sleeping went badly with the window closed.'

I Natal $\square$ e ot ètogo xrapa spalos $\square$ bespokojno. (Ju. Mamleev)

'And Natalia's sleeping went uneasily because of this snore.'

Prisjad $\square$-ka rjadom, čto-to mne ne spitsja.

'Just sit down beside me, (I feel that) I cannot sleep.'

The predicate in negative cannot be accompanied by evaluation adverbs, only intensifiers are allowed (soveršenno ne rabotaetsja 'cannot work at all', nikak ne spitsja 'cannot sleep at all'). But the construction with ne in Russian is not a mere negation of the original meaning. Some verbs in negative without adverbial modifiers may develop an additional (besides the basic meaning) semantic component, similar to that of the Bulgarian construction (see VI below).

The Bulgarian model, contrary to its Russian counterpart, does not accept evaluation modifiers (on the "good - bad" scale), cf. the impossibility to evaluate one's own condition:

*Puši mi se prijatno.

'I feel like smoking gladly.'

or to question such modifier:

*Kak ti se puši?

'How do you feel like smoking.'

Only possible is the integration of intensifiers that mark the intensity of the willingness or unwillingness (mnogo, užasno, adski, xič, kak, kolko etc.):

Adski mi se spi.

'I feel like sleeping terribly.'

Kolko mu se pušeše!

'He felt like smoking so much!'

Nikak ne mi se raboti sega

'I do not feel like working at all today.'

Xič ne mi se izliza dnes!

'I do not feel a bit like going out.'

Due to the fact that the Bulgarian construction, unlike the Russian one, may include verbs of momentary action, the range of admissible temporary locators will be different in the two languages. Bulgarian allows the use of punctual adverbial modifiers of time (cf. Bulgarian Dnes sled rabota rešix, če ne 
mi se pribira vednaga 'Today I decided after work that I did not feel like going home immediately'). Locative adverbial modifiers may be used in Bulgarian with motion verbs to denote the destination:

Ne mu se xodeše do prozoreca. Ne mu se sjadaše zad bjuroto. (P. Vežinov)

'He had no inclination to approach the window. He had no inclination to sit at the desk.'

I na men ne mi se vliza v kazarma.

'Neither do I feel like going to the army.'

while in Russian locators always denote the static position:

$\mathrm{Na}$ dače mne lučše sočinjaetsja.

'My composing goes better at the country cottage.'

Ne spitsja $v$ dušnoj komnate.

'(I feel that) (I) cannot sleep in a stuffy room.'

Rather than being a full-scale counterpart of the Bulgarian construction with the desiderative meaning, the Russian model in its principles of formation and co-occurrence potential is much more similar to the Bulgarian "impersonified subject construction" [5] :

Inače Tatjana e čovek, s kogoto se raboti prijatno.

'Overall Tatiana is a person with whom working goes nicely.'

Mnogo dobre se spi tuk, naistina.

'Sleeping goes very well here, really.'

The impersonified subject construction, just like the Russian model examined above, allows the use of evaluation adverbial modifiers and is marked with the relevant feature "durative". However it does not accept experiencers in the dative, which has to do with the lack of the involuntariness and inexplicability components in its semantics.

\section{Special CaSes}

Despite of the above differences in the semantic interpretation of the Russian and Bulgarian constructions, there are fields of overlap between these models in their relation to the feature «contemporaneous vs. future action».

a) On the one hand, there are a number of Russian verbs that can convey in the discussed model, along with its main meaning of the continuous action, a desiderative meaning, that is the meaning of the inclination of an organism towards the expressed action, similarly to Bulgarian dreme mi se 'I am sleepy', plače mi se 'I feel like crying.' These are some verbs of uncontrolled physiological processes (plakat $\square$ 'cry', dremat $\square$ 'doze') and emotional states (grustit' 'pine', ljubit' 'love'). Cf. Russian:

... čeloveku plačetsja pri odnoj ugroze večnoj razluki. (V. Erofeev)
'... man tends to cry at a mere threat of being separated forever.'

Čto delat', esli ničego ne xočetsja, ne ljubitsja, ne vljubljaetsja?

'What can be done when (one feels that) nothing can be wanted, loved, fallen in love with?'

Moreover, in Russian the inclination toward a future action may be expressed, by analogy, also by predicates of other semantic classes, if they are included in a common enumerative series with the mentioned predicates of state. A negative form of such constructions is quite common to denote an irregular state of affairs, namely an inexplicable inability to experience a certain state:

Ženščiny ne vsegda ljubjat, kogda mužčinam ne streljaetsja, ne pišetsja, ne ljubitsja, ne stroitsja. (V. Al'binin)

'Women are not always approving of (the situation when) men do not tend to shoot, write, love, build.'

It should be noted that the desiderative meaning exists in this Russian model as supplementary to the main one: any of the quoted verbs is capable as well of expressing the meaning of an activity, i. e. that of a successful or unsuccessful action, which is especially salient in the context of a characterizing adverbial modifier:

Pod šum priboja xorošo dremletsja.

'With the rumble of surf dozing goes well.'

V molodosti vsegda burno ljubitsja i burno stradaetsja;

'In youth loving always goes violently and suffering goes violently.'

Ne grustitsja, i ne ljubitsja, i ne vosxiščaetsja, kak ran'še.

'(I feel that) (I) cannot pine, cannot love, cannot admire as before.'

b) On the other hand, when the Bulgarian construction uses a verb having the feature "durative", it can denote not only a potential, but also progressive action:

E, djado, kato si na sto i osem godini, živee li ti se ošte? (V. Petrov)

'Hey, old man, being one hundred and eight years old, is your living still desired by you?'

Izjaždaše vsičko i useštaše, če vse ošte mu se jade. (P. Vežinov)

'He ate everything, but eating was still desired by him.'

In such cases the negative form of the verb of durative action is prevailing, which expresses unwillingness to renew the process:

Ne mi se raboti poveče.

'Working is not desired by me anymore.' 
Ne mi se čaka poveče.

'Waiting is not desired by me anymore.'

To activate this interpretation the presence of a corresponding modifier is required (ošte - in the affirmative, poveče - in the negative).

Overall, the state of the speaker and the action in the Bulgarian model have the same temporal reference as their counterpart in the Russian sentences with the verb xočetsja, where the "desirability / undesirability of the named action may be realized by the subject both in the course of the action and before" [7].

\section{Stylistic PeCUliarities of the RUSSIAN AND BULGARIAN CONSTRUCTIONS}

A number of studies over the last decades emphasized the wide presence of the examined model in Russian. To prove its productivity, various examples from the fiction, poetry, letters of intellectuals and other cases of deliberate language play are presented as evidence. The active use of this model became an individual peculiarity of some persons of letters, such as Marina Tsvetaeva, who had lifted many existing constraints in the formation of this Russian construction:

Kak živëtsja vam - xlopočetsja - Ëžitsja? Vstaëtsja kak? <.. > Kak živëtsja vam - zdorovitsja - Možetsja? Poëtsja - kak?

It should be noted, however, that "irregular" uses of the Russian construction are always stylistically marked. If only stylistically neutral examples are taken into consideration, it becomes clear that the range of verbs used in this model is rather restricted, cf. remarks on the lexicalization of this model in Russian in $[3 ; 6]$. In this regard the Russian construction is clearly incommensurable with its Bulgarian counterpart, where this model has no stylistic coloring and is widely used.

\section{SOME OTHER SLAVIC LANGUAGES}

As far as other Slavic languages are concerned, Serbian reveals similarity to Bulgarian in derivational, semantic and co-occurrence features of this construction:

Ne razgovara mi se sa njim danas.

'I am not inclined to talk to him today.'

Gleda mi se dobar film.

'I feel like watching a good movie.'

In Polish and Czech the construction in question is not so widely present and is affected by various semantic and stylistic constraints, while its meaning (in particular, the presupposed component, which determines the actual nature of the action) is close to the semantics of the Russian construction, including the similar role of modifiers, cf. Czech:

Pracuje se mi dobře.

'My working is going well.' or Polish:

Bardzo trudno mi się pracuje, kiedy nic nie łączy mnie z ludźmi, których fotografuję.

'My working is going very hard when nothing connects me to people I am taking pictures of.'

\section{CONCLUSION}

The Reflexive-with-Dative Construction, apart from Russian, can also be found in the South Slavic languages, where it reveals the same semantic effect of an "internal inclination to an action", "inexplicable ability to do something", but with much more syntactic and stylistic freedom. The discussed differences in the interpretation of the Russian and the South Slavic models and in the conditions licensing their derivation are based on the divergence in the presupposed component (actual or potential status of the action), rather than on the specific senses (involuntary, uncontrolled nature, the effect of "unaccountable forces"), habitually called upon to substantiate the uniqueness of the Russian construction.

\section{REFERENCES}

[1] G. Eason, B. Noble, and I.N. Sneddon, "On certain integrals of Lipschitz-Hankel type involving products of Bessel functions," Phil. Trans. Roy. Soc. London, vol. A247, pp. 529-551, April 1955. (references)

[2] A. Wierzbicka, Semantics, Culture, and Cognition: Universal Human Concepts in Culture-Specific Configurations. Oxford, 1992, p. 425.

[3] Ju. Apresjan, "O Moskovskoj semantičeskoj škole”, Voprosy jazykoznanija, 2005, No. 1, pp. 3-30.

[4] I. Georgiev, Bezlichnye predloženija v russkom i bolgarskom jazykax. Sofia, 1990, pp. 76-82.

[5] J. Penchev, "Ednosăstavni izrečenija", Săvremenni lingvistični teorii: Pomagalo po sintaksis, Plovdiv, 2001, pp. 86-93.

[6] A. Gradinarova, "Bolgarskij sub"ektnyj impersonal i ego russkie funkcional'nye sootvetstvija”, Acta Linguistica, vol. I, No. 1, 2007, pp. 41-54.

[7] B. Norman, Perexodnost'. Zalog. Vozvratnost', Minsk, 1972.

[8] G. A. Zolotova, N. K. Onipenko, M. Ju. Sidorova, Kommunikativnaja grammatika russkogo jazyka, Moscow, 1998, p. 125. 